\title{
The Pilot Test Study of Relationship Between Management Information Systems Success Factors and organizational performance at Sabafon Company in Yemen
}

\author{
Yaser Hasan Al-Mamary, Alina Shamsuddin and Nor Aziati \\ Universiti Tun Hussein Onn Malaysia, Faculty of Technology Management and \\ Business, 86400 Malaysia \\ Yaser_almamary@yahoo.com
}

\begin{abstract}
The use of the management information systems has become necessary for any organization to improve efficiency, productivity, and improve performance in general. The field of management information systems in Yemeni companies still dealing with issues in adopting the technologies and success factors. This study attempts to focus deeply on the factors that lead to successful adoption of management information systems (MIS) in Yemeni organizations. This paper investigates the relationship between technological factors (system quality, information quality, and service quality), organizational factors (top management support, and user training), and people factors (computer self-efficacy, and user experience) with organizational performance, focusing on people who are always associated with MIS in their work. This study found that there are positive correlated relationship between system quality, information quality, service quality, top management support, user training, computer self-efficacy, and user experience with organizational performance at Sabafon Company in Yemen.
\end{abstract}

Keywords: Pilot Test, Management Information Systems, Success Factors, Organizational Performance, Sabafon Company

\section{Introduction}

Management information systems one of the most important achievements in the area of administrative work, which aims to provide reliable, accurate, relevant and complete information to managers toward enhancing of organizational performance in organizations [1]. In addition, management information system one of the most important tools in any organization, which aims to provide quality information in a timely manner to the users of the system to increase the organizational performance and labor productivity [2]. Hasan et al., [3] defined management information systems as type of information systems that take internal data from the system and summarize it to meaningful and useful forms as management reports to use in managerial decision making and support management activities.

In telecommunication companies in Yemen, management information systems enable to compilation, processing and storage of the information; with overall purpose to make that information available on demand in the required format toward improve the organizational performance [1].

Organizational performance is accumulated on the end results of all the organization's work processes and activities. The common measures for organizational performance are organizational productivity and organizational effectiveness. Organizational productivity is a measure of how efficiently employees do their work. Organizational effectiveness is a measure of how appropriate organizational goals are and how well an organization is achieving those goals [4]. 
According to Saeed et al. [5] there are many variables that affect the performance. These variables include manager's attitude, organizational culture, personal problems, job content and financial rewards. All of these variables have positive impact on the performance of the employees except personal problems of the employees that hinders the performance of the employees. According to Luarn \& Huang [6] there are three factors affect performance: task-technology fit, computer self-efficacy, and utilization.

Synthesizing from the literature and interviews with some of the employees at Sabafon company in Yemen, this study developed model compatible with the Yemen's problems.

This study is designed to investigate the relationship between management information systems success factors (technological, organizational, and people) with organizational performance. This is done in order to have a better perspective incorporating a study conducted at Sabafon company in Yemen. Based on the overview of the study, three research objectives are formulated that are described as follows:

RO1. To investigate the relationship between technological factors (system quality, information quality, and service quality) and organizational performance.

RO2. To investigate the relationship between and organizational factors (top management support, and user training) and organizational performance.

RO3. To investigate the relationship between people factors (computer self-efficacy, and user experience) and organizational performance.

Hence, this study presents following hypotheses and intends to test the seven hypothetical statements to be supported or not supported in this study.

H1 - There is a positive correlated relationship between system quality and organizational performance.

$\mathrm{H} 2$ - There is a positive correlated relationship between information quality and organizational performance.

H3- There is a positive correlated relationship between service quality and organizational performance.

H4 - There is a positive correlated relationship between top management support and organizational performance.

H5 - There is a positive correlated relationship between user training and organizational performance.

H6 - There is a positive correlated relationship between computer self-efficacy and organizational performance.

H7 - There is a positive correlated relationship between user experience and organizational performance.

\section{Methods}

A questionnaire developed in this study was based on the comprehensive literature review. The questionnaires are divided into 5 parts with a total of 59 questions. The questionnaire in section $\mathrm{A}$ is about demographic of respondent. The questionnaire in section $\mathrm{B}(\mathrm{I}), \mathrm{B}(\mathrm{II})$, and $\mathrm{B}(\mathrm{III})$ is about technological factors. The questionnaire in section $\mathrm{C}(\mathrm{I})$, and $\mathrm{C}(\mathrm{II})$ is about organizational factors. The questionnaire in section $\mathrm{D}(\mathrm{I})$, and $\mathrm{D}$ (II) is about people factors .Lastly, the questionnaire in section $\mathrm{E}$ is about organizational performance. In this study, it focuses on the relationship between technological factors (system quality, information quality, and service quality) ,organizational factors (top management support, and user training), and people factors (computer self-efficacy, and user experience) with organizational performance. The 
quantitative method is applied to collect all data for this study which is known as survey approach.

Questionnaires are finalized and sent to Sabafon company and 104 sample respondents are gathered for pilot test. Survey data are analyzed through statistical method of analysis using SPSS. Methodological tool of Pearson correlation is used to analyze technically, the relationship between technological, organizational, and people factors with organizational performance.

\section{Conceptual Model}

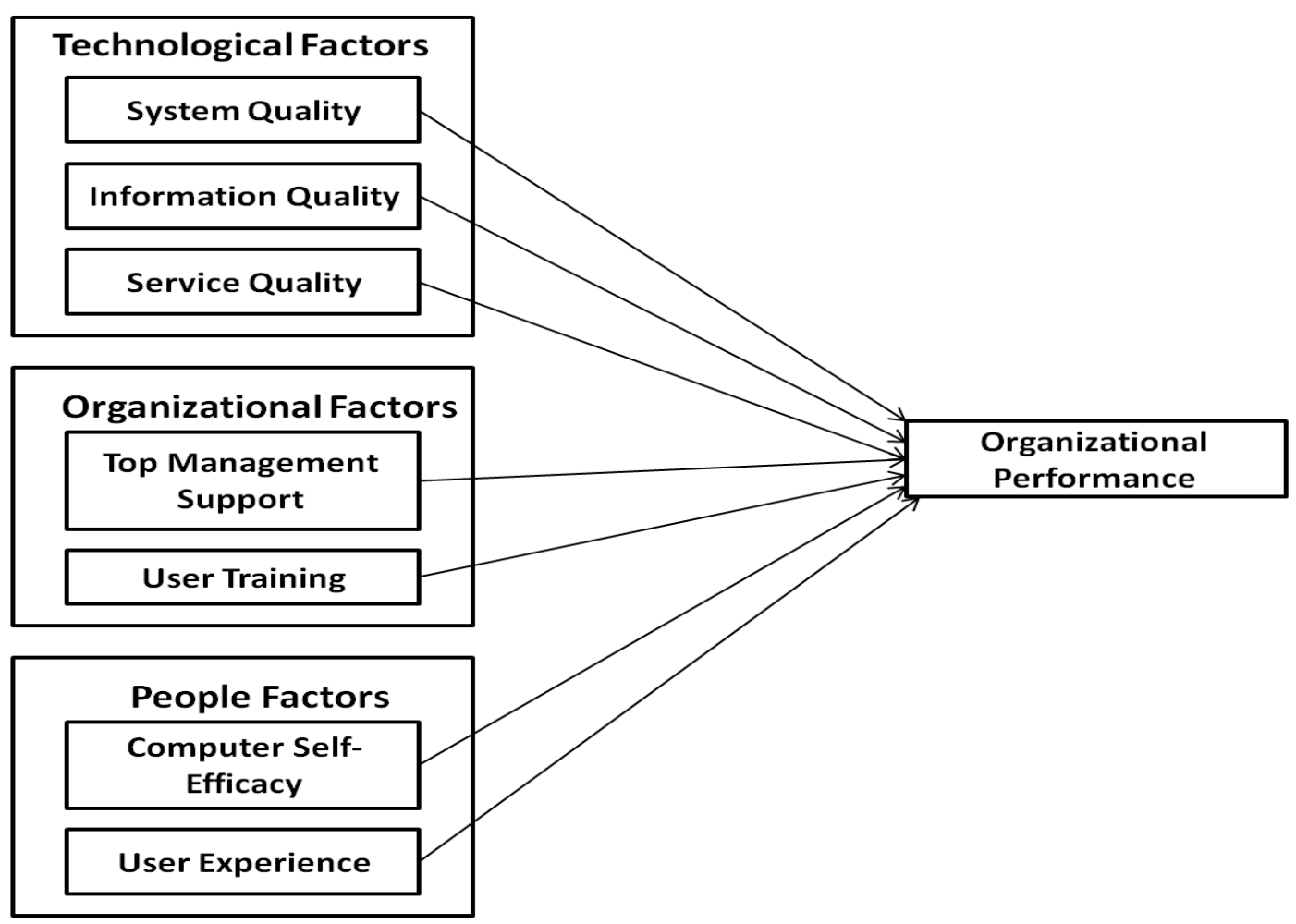

Figure 1. Conceptual Model

\section{Instrument Design}

The questionnaire was prepared on the basis of review of literature and many discussions with consultants and experienced academicians. The responses were collected on seven point liker type scale ranging from strongly disagree to strongly agree (l. Strongly disagree, 2.disagree, 3.Somewhat disagree, 4. Neither agree or disagree, 5. Somewhat agree, 6. Agree, 7. Strongly agree).

The items that used to measure each of the latent variable in the study are summarized in Table 1.

Table 1. Items that Used to Measure the Variables

\begin{tabular}{|l|l|l|}
\hline Concepts & Items & Adopted \\
\hline System Quality & $\begin{array}{l}\text { 1. Ease of use } \\
\text { 2. Ease of learning }\end{array}$ & Petter et al. \\
& $\begin{array}{l}\text { 3. System reliability } \\
\text { 4. Response time }\end{array}$ & \\
\hline
\end{tabular}




\begin{tabular}{|c|c|c|}
\hline & $\begin{array}{l}\text { 5. System flexibility } \\
\text { 6. Sophistication } \\
\text { 7. Intuitiveness }\end{array}$ & \\
\hline Information Quality & $\begin{array}{l}\text { 1. Relevance } \\
\text { 2. Understandability } \\
\text { 3. Accuracy } \\
\text { 4. Conciseness } \\
\text { 5. Completeness } \\
\text { 6. Timeliness } \\
\text { 7. Usability }\end{array}$ & $\begin{array}{l}\text { Petter et al. } \\
\text { [7] }\end{array}$ \\
\hline Service Quality & $\begin{array}{l}\text { 1. Technical support teams give prompt service } \\
\text { to users (responsiveness). } \\
\text { 2. Technical support teams provide accurate } \\
\text { service. } \\
\text { 3. Technical support teams provide dependable } \\
\text { service (reliability). } \\
\text { 4. Technical support teams have technical } \\
\text { competence. } \\
\text { 5. Technical support teams have users' best } \\
\text { interests at heart(empathy of the personnel } \\
\text { staff). } \\
\text { 6. Technical support teams have the knowledge } \\
\text { to do their job well (assurance). }\end{array}$ & $\begin{array}{l}\text { Delone \& } \\
\text { Mclean [8] } \\
\& \text { Petter et } \\
\text { al. [7] }\end{array}$ \\
\hline $\begin{array}{ll}\text { Top } & \text { Management } \\
\text { Support } & \end{array}$ & $\begin{array}{l}\text { 1. Management is aware of the benefits that can } \\
\text { be achieved with the use of the system. } \\
\text { 2. Management always supports and } \\
\text { encourages the use of the system for job-related } \\
\text { work. } \\
\text { 3. Management provides most of the necessary } \\
\text { help and resources to enable people to use the } \\
\text { system. } \\
\text { 4. Management is really keen to see that people } \\
\text { are happy with using the system. } \\
\text { 5. Management provides good access to } \\
\text { hardware resources when people need them. } \\
\text { 6. Management provides good access to various } \\
\text { types of software when people need them. }\end{array}$ & $\begin{array}{l}\text { Igbaria et al. } \\
\text { [9] }\end{array}$ \\
\hline User Training & $\begin{array}{l}\text { 1. Our company offers training to use the } \\
\text { system . } \\
\text { 2. Our company offers internal training. }\end{array}$ & $\begin{array}{l}\text { Igbaria et al. } \\
\text { [9] }\end{array}$ \\
\hline
\end{tabular}




\begin{tabular}{|c|c|c|}
\hline & $\begin{array}{l}\text { 3. Our company offers external training. } \\
\text { 4. Our company offers training to use } \\
\text { Microsoft office application } \\
\text { 5. Our company offers training to use } \\
\text { application packages. } \\
\text { 6. Our company offers training to use operation } \\
\text { systems }\end{array}$ & \\
\hline $\begin{array}{l}\text { Computer } \quad \text { Self- } \\
\text { Efficacy }\end{array}$ & $\begin{array}{l}\text { 1. I can understand how the system work } \\
\text { 2. I am confident that I can learn how to use the } \\
\text { system. } \\
\text { 3. I feel comfortable using the system on my } \\
\text { own . } \\
\text { 4. I can easily use any of the functions in the } \\
\text { system. } \\
\text { 5. I be able to use the system even if there is no } \\
\text { one around to show me how to use it ( I can use } \\
\text { the system without help from others). } \\
\text { 6. I have the knowledge and skills required to } \\
\text { use the system. }\end{array}$ & $\begin{array}{l}\text { Igbaria \& } \\
\text { Iivari [10] } \\
\& \\
\text { Brown [11] }\end{array}$ \\
\hline User Experience & $\begin{array}{l}\text { 1. I have experience in using the various types } \\
\text { of IS in the company. } \\
\text { 2. I have experience in using Microsoft office } \\
\text { application } \\
\text { 3. I participation in feasibility studies. } \\
\text { 4.I participation in requirements analysis. } \\
\text { 5.I have experience in using programming } \\
\text { languages . } \\
\text { 6.I participation in design of computerized } \\
\text { information systems. }\end{array}$ & $\begin{array}{l}\text { Igbaria \& } \\
\text { Iivari [10] }\end{array}$ \\
\hline $\begin{array}{l}\text { Organizational } \\
\text { Performance }\end{array}$ & $\begin{array}{l}\text { 1. Productivity } \\
\text { 2. Efficiency } \\
\text { 3. Profitability } \\
\text { 4. Market value } \\
\text { 5.Competitive advantage } \\
\text { 6. Cost reduction } \\
\text { 7. Revenue enhancement } \\
\text { 8.Overall firm performance }\end{array}$ & $\begin{array}{l}\text { Melville et } \\
\text { al. [12] }\end{array}$ \\
\hline
\end{tabular}




\section{Reliability Test for Pilot Test}

Reliability is an assessment of the degree of consistency between multiple measurement of a variable. Reliability extent to which a variable or set of variables is consistent in what it is intended to measure. The reliability coefficient assesses the consistency of the entire scale, with cronbach's alpha. The generally agreed upon lower limit for cronbach's alpha is 0.70 , although it may decrease to 0.60 in exploratory research [13]. According to Awang [14] the reliability can be assessed through internal reliability (Cronbach alpha $>=0.70$ ).

The Cronbach's coefficient alpha was calculated for each field of the questionnaire. Table 2 shows the values of Cronbach's Alpha for each construct. Cronbach's Alpha equals 0.863 for the entire questionnaire which indicates an very good reliability of the entire questionnaire.

Table 2. Reliability Test for Pilot Test

\begin{tabular}{|c|c|c|}
\hline Item & Cornbach's Alpha & N of Items \\
\hline SyQ & 0.852 & 7 \\
\hline IQ & 0.846 & 7 \\
\hline SerQ & 0.846 & 6 \\
\hline TMS & 0.847 & 6 \\
\hline UT & 0.861 & 6 \\
\hline CSE & 0.862 & 6 \\
\hline UE & 0.871 & 6 \\
\hline OP & 0.823 & 8 \\
\hline
\end{tabular}

\section{Demographic Analysis}

Table 3 shows the following: Firstly, all the respondents from Sabafon company. Secondly, $50 \%$ of the respondents from information system department, $50 \%$ of the respondents from customer service department. Thirdly, $88.5 \%$ of the respondents are male, and $11.5 \%$ are female. Fourthly , $51.9 \%$ of the age of the respondents less than 30 , $46.2 \%$ of the age of the respondents between 30 and $40,1.9 \%$ of the age of the respondents between 40 and 50, and no respondents above 50. Fifthly, $1.9 \%$ of the respondents have high school, $6.7 \%$ of the respondents have diploma, $81.7 \%$ of the respondents have bachelor degree, $9.6 \%$ of the respondents have master degree, and no one have PhD. Sixthly, $24 \%$ of the respondents are administrative staff, $41.3 \%$ of the respondents are technical support staff, $2.9 \%$ of the respondents are heads of departments, $2.9 \%$ of the respondents are managers, and $28.8 \%$ of the respondents from another position. Finally , $17.3 \%$ of the respondents working experience less than 2 years, $26.9 \%$ of the respondents working experience between 2 and 4 years, $24 \%$ of the respondents working experience between 4 and 6 years, $13.5 \%$ of the respondents working experience between 6 and 8 years, and $18.3 \%$ of the respondents working experience above 8 years.

Table 3. Demographic Profiles

\begin{tabular}{|c|c|c|c|}
\hline & & Frequency & Percent \\
\hline Company & Sabafon & 104 & 100.0 \\
\hline \multirow{4}{*}{ Department } & Information Systems/ IT & 52 & 50.0 \\
\cline { 2 - 4 } & Customers Service & 52 & 50.0 \\
\cline { 2 - 4 } & Accounting and Finance & 0 & 0.0 \\
\cline { 2 - 4 } & Human Resource & 0 & 0.0 \\
\cline { 2 - 4 } & Marketing and Sales & 0 & 0.0 \\
\hline
\end{tabular}




\begin{tabular}{|l|c|c|c|}
\hline Gender & Male & 92 & 88.5 \\
\cline { 2 - 4 } & Female & 12 & 11.5 \\
\hline \multirow{4}{*}{ Age Group } & Less than 30 & 54 & 51.9 \\
\cline { 2 - 4 } & 30 less than 40 & 48 & 46.2 \\
\cline { 2 - 4 } & 40 less than 50 & 2 & 1.9 \\
\hline \multirow{4}{*}{ Education } & Above 50 & 0 & 0.0 \\
\cline { 2 - 4 } & High School & 2 & 1.9 \\
\cline { 2 - 4 } & Diploma & 7 & 6.7 \\
\cline { 2 - 4 } & Bachelor & 85 & 81.7 \\
\hline \multirow{4}{*}{ Designation } & Master & 0 & 9.6 \\
\cline { 2 - 4 } & PhD & 25 & 24.0 \\
\cline { 2 - 4 } & Administration Staff & 43 & 41.3 \\
\cline { 2 - 4 } & Technical Support Staff & 3 & 2.9 \\
\hline \multirow{4}{*}{$\begin{array}{l}\text { Wead of Department } \\
\text { Experience }\end{array}$} & Manager & 3 & 2.9 \\
\cline { 2 - 4 } & Others & 18 & 17.3 \\
\cline { 2 - 4 } & Less than 2 & 28 & 26.9 \\
\cline { 2 - 4 } & 2 - less than 4 & 25 & 13.5 \\
\cline { 2 - 4 } & 4 - less than 6 & 14 & 18.3 \\
\hline
\end{tabular}

\section{Correlation Analysis and Summary of the Findings}

This section shows the findings based on the correlation analysis. Table 4 shows the correlation analysis between the management information systems success factors and organizational performance for the pilot test study.

Table 4. Correlations

\begin{tabular}{|c|l|}
\hline & OP \\
\hline SyQ Pearson Correlation & $0.261^{* *}$ \\
Sig. (2-tailed) & 0.007 \\
N & 104 \\
\hline IQ Pearson Correlation & $0.302^{* *}$ \\
Sig. (2-tailed) & 0.002 \\
N & 104 \\
\hline SerQ Pearson Correlation & $0.317^{* *}$ \\
Sig. (2-tailed) & 0.001 \\
N & 104 \\
\hline TMS Pearson Correlation & $0.429^{* *}$ \\
Sig. (2-tailed) & 0.000 \\
N & 104 \\
\hline UT Pearson Correlation & $0.201^{*}$ \\
Sig. (2-tailed) & 0.041 \\
\hline
\end{tabular}




\begin{tabular}{|c|l|}
\hline N & 104 \\
\hline CSE Pearson Correlation & $0.298^{* *}$ \\
Sig. (2-tailed) & 0.002 \\
N & 104 \\
\hline UE Pearson Correlation & $0.204^{*}$ \\
Sig. (2-tailed) & 0.038 \\
N & 104 \\
\hline
\end{tabular}

** Correlation is significant at the 0.01 level (2-tailed).

* Correlation is significant at the 0.05 level (2-tailed).

Based on Table 4, it can be deduced that there are a positive correlated relationship between technological, organizational, and people factors with organizational performance. And Table 5 shows the results of the hypothesis in the findings.

Table 5. Summary of the Findings

\begin{tabular}{|l|l|l|}
\hline No & The Research Hypothesis & The Results \\
\hline H1 & $\begin{array}{l}\text { There is a positive correlated relationship between system } \\
\text { quality and organizational performance. }\end{array}$ & Supported \\
\hline H2 & $\begin{array}{l}\text { There is a positive correlated relationship between information } \\
\text { quality and organizational performance. }\end{array}$ & Supported \\
\hline H3 & $\begin{array}{l}\text { There is a positive correlated relationship between service quality } \\
\text { and organizational performance. }\end{array}$ & Supported \\
\hline H4 & $\begin{array}{l}\text { There is a positive correlated relationship between top management } \\
\text { support and organizational performance. }\end{array}$ & Supported \\
\hline H5 & $\begin{array}{l}\text { There is a positive correlated relationship between user training and } \\
\text { organizational performance. }\end{array}$ & Supported \\
\hline H6 & $\begin{array}{l}\text { There is a positive correlated relationship between computer self- } \\
\text { efficacy and organizational performance. }\end{array}$ & Supported \\
\hline H7 & $\begin{array}{l}\text { There is a positive correlated relationship between user experience } \\
\text { and organizational performance. }\end{array}$ & Supported \\
\hline
\end{tabular}

\section{Conclusion}

The purpose of this study was to address the three research questions that evaluate the relationship between technology factors, organizational factors, and people factors with organization performance. Data was collected using a survey questionnaire. The resultant 104 usable responses were analyzed with Pearson correlation .The proposed model of this study is built from review of literature and interviews with some of the employees in Sabafon company in Yemen, this study developed model compatible with the Yemen's problems. This study found that there are positive correlated relationship between technological, organizational, and people factors with organizational performance at Sabafon company in Yemen. 


\section{Acknowledgement}

The authors would like to thank Faculty of Technology Management and Business UTHM for help. In addition thank ministry of Higher Education and Scientific Research in Yemen for support.

\section{References}

[1] Al-Mamary, Y.H., Shamsuddin, A. \& Aziati, N. (2014) Factors affecting successful adoption of management information systems in organizations towards enhancing organizational performance, American Journal of Systems and Software, 2(5), pp. 121-126.

[2] Al-Mamary, Y.H., Shamsuddin, A. \& Aziati, N. (2014) Proposed Model For The Successful Implementation Of Management Information Systems In Yemeni Organizations, Journal of Management and Science, 4(3).

[3] Hasan, Y., Shamsuddin, A. \& Aziati, N. (2013). The impact of management information systems adoption in managerial decision making: A review. Management, 8(4), pp. 010-017.

[4] Robbins \& Coulter, M. (2002). Management. Prentice Hall7, th edition.

[5] Saeed, R., Mussawar, S., Lodhi, R.N., Iqbal, A., Nayab, H.H. \& Yaseen, S. (2013). Factors affecting the performance of employees at work place in the banking sector of pakistan. Middle-East Journal of Scientific Research, 17(9), pp. 1200-1208.

[6] Luarn, P. \& Huang, K.L. (2009). Factors influencing government employee performance via information systems use: an empirical study. Electronic Journal of EGovernment, 7(3), pp. 227-240.

[7] Petter, S., DeLone, W. \& McLean, E. (2008). Measuring information systems success: models, dimensions, measures, and interrelationships. European Journal of Information Systems, 17(3), pp. 236263.

[8] Delone \& Mclean,W.H. (2003). The delone and mclean model of information systems success: a tenyear update. Journal of management information systems, 19(4), pp. 9-30.

[9] Igbaria, M., Zinatelli, N., Cragg, P. \& Cavaye, A.L. (1997). Personal computing acceptance factors in small firms: a structural equation model. MIS quarterly, pp.279-305.

[10] Igbaria \& Iivari, J. (1995). The effects of self-efficacy on computer usage. Omega, 23(6), pp. 587-605.

[11] Brown, I.T. (2002). Individual and technological factors affecting perceived ease of use of web-based learning technologies in a developing country. The Electronic Journal of Information Systems in Developing Countries, 9.

[12] Melville, N., Kraemer, K. \& Gurbaxani, V. (2004). Review: Information technology and organizational performance: An integrative model of it business value. MIS quarterly, 28(2), pp. 283-322.

[13] Hair, J., Anderson, R., Tatham, R. \& Black,W. (2010). Multivariate Data Analysis $7^{\text {th }}$ edition Prentice Hall.

[14] Awang, Z. (2012). Structural equation modeling using AMOS graphic. Penerbit Universiti Teknologi MARA.

\section{Authors}

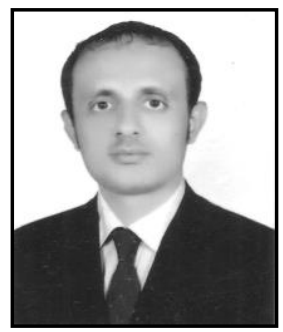

Yaser Hasan Salem Al-Mamary, is a $\mathrm{PhD}$ student at University of Tune Hussein Onn Malaysia .He is from Yemen. He will receive his $\mathrm{PhD}$ degree from Faculty of Technology Management and Business. His research and publications focus on topics such as Management Information Systems (MIS), IS Success, Technology Management, Information Systems, and Technology Adoption.

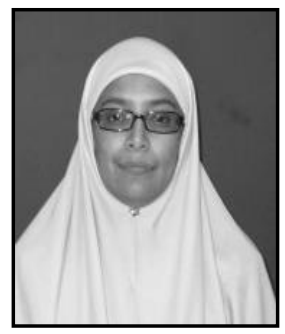

Associate. Prof. Dr Alina Binti Shamsuddin, is Head of the Department of Academic Programs (JPPA) Centre for Development and Academic Training UTHM. Her research and publications focus on technology management - supply chain management, Performance Measurement System, and Innovation Management. 


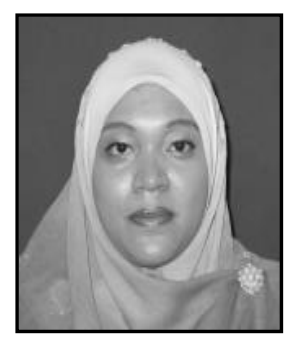

Dr. Nor Aziati BT Abdul Hamid, is Senior Lecturer at Faculty of Technology Management and Business UTHM. Her research and publications focus on IT Outsourcing, Knowledge Management, and Knowledge Transfer. 